\title{
Using public administration theory to analyze public innovation ${ }^{1}$
}

\author{
Albert Meijer and Frank Bannister \\ E-mail: A.J.Meijer@uu.nl
}

Received 27 December 2009

The study of innovation associated with ICT has been strong on the agenda of academics for many years. This focus can be seen as a response to the continuous effort of practitioners in public administration to innovate both public organizations and policies through the use of information and communication technologies. Such innovations offer the prospect of improving public administration without messy political choices being necessary, with the rhetorical claim that everyone concerned will benefit, both individual consumers and the organizations engaged in service provision (Cf. [8]). Academics have criticized these naive assumptions and they have convincingly pointed out that the value of innovation in the public sector cannot be directly compared to innovation in the private sector [2,3]. There is now a substantial literature about innovation in the public sector highlighting how processes of innovation can be strengthened [1-5].

Why, then, do we present another set of papers on innovation in the public sector? Our main reason is that previous studies have not been successful in interpreting ICT-driven or -enabled innovation by reference to the core literature in Public Administration. Many publications on innovation in the public sector take Rogers' work [6] on the diffusion of innovations as their main theoretical framework [12,13] whilst many $[14,15]$ in the information systems literature focus on various versions of the Technology Acceptance Model (TAM) and its derivates [9]. Although we do acknowledge that studies of innovation need to relate their works to Rogers' and Davis' seminal research, the focus on the diffusion of innovations makes it difficult to connect this work to mainstream theories in Public Administration. The set of papers in this issue of Information Polity will connect discussions about innovation in the public sector more directly to the main body of literature in Public Administration. We accept that this 'main body' of literature is hard to define with precision but we refer here to theories discussed in standard text books on Public Administration: theories on the functioning of public organizations, democratic arrangements and public policy-making.

The lack of integration of research findings about the use of technology in government into the core of Public Administration is, as one of us has pointed out before [10], a more general problem. Researchers have tended to develop a separate domain from such studies, which in turn facilitates communication within this community whilst limiting the value of this research for a broader audience. Additionally, a

\footnotetext{
${ }^{1}$ Selected papers from the 2008 conference of the European Group of Public Administration.
} 
failure to use more general theories from Public Administration limits our understanding of the specific characteristics of innovation processes in the public sector. Institutional and evolutionary theories have been used $[2,3]$ but more specific theories on policy-making, regulation and organizational performance are largely ignored. These omissions limit the value of studies into innovation in the public sector for the larger academic field of Public Administration. This special issue forms a start and a plea for integrating theories on innovation with theories from Public Administration.

This issue starts with a discussion of a technology, and decision making about that technology, as a public innovation. It does so by examining the case of closed circuit television (CCTV). This technology has been discussed before in this journal by the same author [7], but here William Webster looks back at the accumulated experience of many years of large scale CCTV deployment in the UK. He uses CCTV as a case study for exploring the rationality of policy-making processes. Innovation is analyzed with the use of theories on policy-making. The core point that he makes is the intriguing one that the expanding use of this technology has not and is not dependent on evidence supporting its value. This failure to connect implementation of an innovation with its actual impact illustrates the importance of evidence based decision making and the risks from ideological, theory driven (or even wishful), thinking when it comes to technological change. Here we have a case where the inadequacy (or even absence of) of decision making has resulted in a policy whose rationale would seem to be driven more by poorly informed public opinion than by the facts. Policy makers aim to create the impression of being rational whereas Webster's analysis clearly indicates that a political rationality guides the decisions about CCTV. The implication is that innovative technologies can need new ways of evaluation and policy making if they are to be used sensibly and effectively. In spite of the lack of evidence for its effectiveness, CCTV, a technology which is not only expensive, but which carries considerable social risks, remains popular with policy makers.

In their paper, Stefan Soeparman, Hein van Duivenboden and Teun Oosterbaan shift the focus away from technology to an interorganizational function as an innovative arrangement. Theories about interorganization collaboration are combined with innovation theory to understand the new entities they call 'infomediary'. They describe 'infomediaries' as temporary initiatives that have been founded to support local collaboration between organizations. They discuss the concept of collaborative innovation and how these organisations provide an interface between users and the technology and are thus a form of enabler, supplying the missing skill sets and/or expertise to allow users to make effective use of a technological innovation. They link, as the authors point out, technological, informational and business domains and the innovations in each of these. The authors' specific analysis highlights a number of different functions of 'infomediaries' in organization cooperation: symbolic analysts, discursive instigators and bricoleurs. They argue against a 'one-size-fits-all' approach and emphasize that the value of these arrangements depends on the fit with local and institutional conditions. The absence of such infomediaries in the use of CCTV sits in marked contrast to the examples provided here. Infomediaries, it seems, contribute both to a rational adoption of technology and an effective one.

The third contribution in this issue on innovative arrangements takes us to the domain of policy instruments. Meijer and Homburg expand policy instrument theory when they claim that a fourth category of policy instruments needs to be added to existing tools. The 'pillory' is an innovative arrangement which differs in several ways from the 'carrot', the 'stick' and the 'sermon' as a way of influencing public behaviour. They show how inspection agencies have made public certain information so as to enhance compliance with laws and regulations. The principle is one of moving from prescriptive, formal regulation to open information with resultant reduction in bureaucracy and increases in the freedom of citizens to make their own decisions. On the basis of their empirical findings Meijer and Homburg argue 
that the rise of this innovative regulatory instrument fits the changing role of government in a network society and that in addition to their other virtues, such methods can be cost effective. In one sense, this is an administrative innovation enabled by technology which is the inverse of the situation in the Soeparman et al paper, but it again demonstrates the symbiotic nature of the ICT and the non-ICT in the effective spread of innovation.

The next contribution takes us to theories about policy transfer and the role of structures in technology diffusion. In their paper, Karl Lofgren and William Webster study the convergence and divergence of policy embedded in the policy transfer process surrounding the implementation of privacy regulations in four European countries. Here the technology creates the problem, thereby triggering a need for innovation elsewhere - in this instance in privacy policy. However this innovation in turn requires innovation in structures and processes and the latter has been slow to happen. Policy transfer is a complex process involving multiple exchanges at different levels as well as a range of actors, agencies and instruments which are shaped by powerful vested interests and which are far from uniform in practice. Lofgren and Webster explore the way in which the policy is both formed and implemented. While the mode of formation, where policy itself is a compromise between various sectional and national perspectives, helps somewhat in this, implementation remains uneven due, in this case, to slowness in the emergence of structural innovation and reliance on traditional levels and modes of communication. As with Webster's paper, this paper illustrates the problems that arise when administrative innovation does keep pace with technological innovation.

The final contribution about innovative arrangements focuses on the Europeanization of e-government policies. Ignacio Criado uses theories about Europeanization to study whether European Union (EU) institutions shape national e-government policies and strategies. He argues convincingly that we need to study European policies in order to understand national e-government policies. In this paper, the innovation in question is the broad deployment of e-government. He examines the range of techniques used by the EU to attempt to diffuse e-government innovation throughout the Union including use of a benchmarking exercise which sought to promulgate a particular model of e-government maturity. The use of benchmarking, whilst not without its critics [11], was innovative and effective. He concludes that EU institutions operated successfully during the last decade in promoting e-government convergence on discourse, paradigms and beliefs. The EU has also managed to stimulate policy learning and mutual adjustment in member states. Thus innovation in administration has fostered and facilitated deployment of technological innovation.

This overview shows how a range of theories from the mainstream of Public Administration are used to enhance our understanding of innovation in the public sector and how innovation in ICT and in other aspects of public administration interact to create synergistic impacts. Additionally, these papers form part of an effort to reconnect the study of innovation in the public sector to the mainstream literature in Public Administration. The study of innovations is connected to theories about policymaking (Webster), to interorganizational theory (Soeparman, Van Duivenboden and Oosterbaan), to theories about policy instruments (Meijer \& Homburg), policy transfer (Lofgren \& Webster) and theories about Europeanization (Criado).

Thus, this issue demonstrates how innovation in the public sector must be understood from two different theoretical perspectives: theories about innovation per se and specific theories from mainstream public administration. As academics who study the interface between technology and public administration, we need to be able to connect these streams of literature. The authors in this issue succeed in combining these discourses and make this issue a modest contribution to our understanding of the 'information polity'. 


\section{References}

[1] M. Veenswijk, ed., Organizing Innovation. New Approaches to Cultural Change and Intervention in Public Sector Organizations, 2006.

[2] V. Bekkers, H. van Duivenboden and M. Thaens, eds, Information and Communication Technology and Public Innovation, Assessing the ICT-Driven Modernization of Public Administration. Amsterdam: IOS, 2006.

[3] H. van Duivenboden and M. Thaens, ICT-driven innovation and the culture of public administration: A contradiction in terms? Information Polity 13(3-4) (2008), 213-232.

[4] O. Pärna and N. von Tunzelmann, Innovation in the public sector: Key features influencing the development and implementation of technologically innovative public sector services in the UK, Denmark, Finland and Estonia, Information Polity 12(3) (2007), 109-125.

[5] V. Bekkers, Modernization, public innovation and information and communication technologies: The emperor's new clothes? Information Polity 12(3) (2007), 103-107.

[6] E.M. Rogers, Diffusion of Innovations, Glencoe: Free Press, 1964.

[7] W. Webster, Closed circuit television and governance: the eve of a surveillance age, Information Infrastructure and Policy 5(4) (1996), 253-263.

[8] R. de Wilde, De Voorspellers, Een Kritiek op de Toekomstindustrie. De Balie, Amsterdam, 2000.

[9] F.D. Davis, Perceived usefulness, perceived ease of use, and user acceptance of information technology, MIS Qutart 13 (1989), 319-339.

[10] A. Meijer, Why don't they listen to us? Reasserting the role of ICT in Public Administration, Information Polity 12(4) (2007), 233-242.

[11] F. Bannister, The curse of the benchmark: an assessment of the validity and value of e-government comparisons, International Institute of Administrative Sciences 73(2) (2007), 171-188.

[12] K.L. Kraemer and J.L. Perry, Innovation and computing in the public sector: A review of research, Knowledge, Technology and Policy 12(1) (1999), 3-18.

[13] E. Korteland and V. Bekkers, Diffusion of E-government innovations in the Dutch public sector: The case of digital community policing, Information Polity 2(3) (2007), 139-150.

[14] P.-Y. Chu, T.-Z. Wu and C.-H. Lee, Technology acceptance in public sector: an empirical study of a Knowledge Management System in Kaohsiung City Government, International Journal of Management and Decision Making 10(5-6) (2009), 341-358.

[15] P.Y.K. Chau and P.J. Hu, Examining a Model for Information Technology Acceptance by Individual Professionals: An Exploratory Study, Journal of Management Information Systems 18(4) (2002), 191-229. 